\title{
KETERLIBATAN PENGASUHAN AYAH SEBAGAI ORANG TUA TUNGGAL DENGAN ANAK PEREMPUANNYA SETELAH TERJADINYA PERCERAIAN (STUDI KASUS KOMUNIKASI ANTARPRIBADI DI DESA KWANGSAN, KECAMATAN JUMAPOLO)
}

\author{
Denny Astuti \\ Program Studi Ilmu Komunikasi \\ Universitas Muhammadiyah Surakarta \\ Email : denny.ladyrose@gmail.com
}

\begin{abstract}
Being a single parent is not easy especially for father, and caring for his girls are still under age of 12 years old. Beside for suffice the needs of the family of an themselves a father is a single parent should parenting is independent. The purpose of the research to describe how to engagement parenting father as a single parent to his daughter after the occurance of divorce. This research using descriptive qualitative method with the approach of communication interpersonal. The object of this research consist of three father became a single parent because of the background of divorce in Jumapolo subdistrict. The technique of collecting data using semi-structured interview. The method of analysing data using descriptive analysing. The result of this research suggests that: (1) the communication interpersonal conducted father as a single parent to this child to give understanding of the family is not explained about divorce but give understanding of the work of this mother, (2) engagement parenting conducted in independent and not involved to the other, (3) the responsibility of father when leaving the girls with entrusting to this family, (4) accessibility is a single parent, father always give time to accompany for playing and activities his child everyday. It can be concluded that the involvement parenting father as a single parent to his daughter is directly in all fulfillment needs.
\end{abstract}

Keywords: single parent, parenting involvement, interpersonal communication

\section{A. PENDAHULUAN}

Keluarga adalah unit terkecil dari masyrakat. Menurut Djamarah (2004), keluarga adalah sebuah institusi yang terbentuk karena ikatan perkawinan. Komunikasi adalah suatu hal yang pasti terjadi dalam kehidupan, termasuk dalam sebuah keluarga. Komunikasi yang sering kita amati adalah komunikasi antarpribadi dalam sebuah keluarga. Komunikasi antarpribadi adalah sebuah proses komunikasi yang berlangsung dua orang atau lebih secara tatap muka (Cangara, 2002).

Keluarga idealnya terdiri dari ayah, ibu, dan anak. Setiap anggota pun mempunyai peran masing-masing, namun kondisi tersebut tidak selalu dapat terwujud karena adanya beberapa faktor, salah satunya adalah faktor perceraian. Banyak hal yang melatar belakangi terjadinya perceraian dan perceraian itu sendiri mengakibatkan efek negatif bagi anak-anak yang menjadi korban dari orang tuanya. Kurangnya kesejahteraan psikologis adalah salah satu efek dari perceraian orang tua. Kesejahteraan psikologis dalam hal ini menyangkut hal kepribadian, kepuasan hidup, kepercayaan diri, komunikasi, dan aktivitas sehari-hari (Kume, 2015). Keluarga yang hubungan antar anggotanya tidak harmonis, penuh konflik, atau gapcommunication, dapat mengembangkan masalah kesehatankesehatan mental (Prayoga, 2013).

Orang tua tunggal dalam pengertian psikologis adalah orang tua yang terdiri 
dari ayah maupun ibu yang siap menjalani tugasnya dengan penuh tanggung jawab sebagai orangtua tunggal. Jika dia mampu mengurus anak-anak, berani dan bertanggung jawab dengan segala resikonya dalam mengasuh anak itulah di sebut orang tua tunggal. Pertaruhan orang tua tunggal di sini mengenai tanggung jawabnya. Tak mudah memang menjadi orang tua tunggal, apa lagi dimasa-masa awal perpisahan dengan pasangan hidup baik karena perceraian maupun kematian (Sari, 2015).

Menurut Badan Pusat Statistik Indonesia dalam data Penduduk Berumur 10 Tahun Keatas Menurut Wilayah dan Status Perkawinan Indonesia di Provinsi Jawa Tengah per tahun 2015 adalah wanita yang cerai hidup sebanyak 294.330 orang, sedangkan cerai mati sebanyak 150.670 orang. Kemudian laki-laki yang cerai hidup sebanyak 117.891 orang, dan cerai mati sebanyak 301.649 orang ("www.bps.go.id," 2015). Dapat dilihat bahwa ibu sebagai orang tua tunggal lebih banyak jumlahnya dari seorang ayah. Di Kecamatan Jumapolo, khususnya desa Kwangsan dalam empat tahun terakhir ini kasus perceraian mengalami peningkatan. Dilihat dari data di kantor Kelurahan Kwangsan per bulan Juli tahun 2016, pada tahun 2013 ada kasus perceraian sebanyak 5 orang, tahun 2014 sebanyak 7 orang, tahun 2015 sebanyak 9 orang, dan pada tahun 2016 sampai bulan Juli sebanyak 8 orang. Dalam pandangan masyarakat juga demikian, ibu sebagai orang tua tunggal terlihat biasa dan tidak dianggap peran yang sulit untuk dijalankan. Begitu pula di negara barat seperti Amerika Serikat dan Eropa, pengasuhan anak di bawah ayahnya masih kurang dominan dan belum bisa diterima oleh masyarakat walaupun banyak juga perempuan yang saat ini memilih untuk bekerja di luar rumah atau wanita karier (Kume, 2015). Masyarakat akan memiliki pandangan yang berbedabeda tentang orang tua tunggal. Di sisi lain orang tua tunggal harus dapat memberikan pengertian, lebih sabar dan tegar dalam menghadapi masalah dalam keluarganya
(Prayoga, 2013). Sejalan dengan pernyataan (Purbasari \& Putri, 2015) bahwa pembagian peran dan maupun pembagian tugas rumah tangga yang adil antara suami dan istri terkadang masih dipengaruhi oleh cara pandang masyarakat mengenai peran gender yang cenderung memposisikan wanita untuk selalu berperan pada wilayah domestik. Wilayah domestik di sini artinya adalah bekerja sebagai ibu rumah tangga saja mengurus rumah dan seisinya. Hal ini membuat peneliti tertarik melakukan penelitian yang berfokus pada ayah yang berperan sebagai orang tua tunggal.

Orang tua tunggal biasanya akan merasa lebih tertekan daripada orang tua utuh dalam kemampuan mengasuh sebagai orang tua pada umumnya. Kemampuan orang tua ini nantinya dapat berpengaruh pada bagaimana si orang tua mengasuh anaknya. Orang tua tunggal yang tidak mempunyai pasangan untuk tempat berbagi mengasuh anak akan berpengaruh pada perkembangan psikologi anak (Prayoga, 2013). Parke dalam Kume (2015), mengatakan bahwa keterlibatan seorang ayah dalam pengasuhan anak akan menciptakan efek yang positif dibandingkan anak dalam pengasuhan ibu saja walaupun jika pengasuhan dilakukan oleh kedua orang tua yang utuh maka efeknya akan lebih signifikan. Efek lain dari keterlibatan ayah dalam pengasuhan anak adalah kemampuan hubungan sosialnya akan terhambat atau terganggu. Selaras dengan pernyataan Barnet dan Kibra dalam (Katorski, 2003) bahwa hubungan yang positif antara ayah dengan anak akan berpengaruh baik dalam perkembangan psikologisnya, sementara hubungan yang negatif diperkirakan dapat membuat tekanan psikologis pada anak. Melihat pernyataan ini dapat dikatakan bahwa pada umumnya mempunyai hubungan yang baik dengan ayah menjadi suatu hal yang penting untuk di perhatikan karena menyangkut perkembangan psikologis anak terlebih untuk anak yang masih di bawah umur 12 tahun.

Menjadi orang tua tunggal tentu saja 
tidak mudah bagi seorang ayah, yang memberatkan lagi adalah anggapan dari masyarakat yang sering memojokkan para ayah yang dianggap tidak maksimal kemudian hal tersebut dapat mempengaruhi pikiran seorang anak (Dian, 2012). Namun menurut Lee, Khuser, dan Cho (2007) hubungan ayah dengan anak perempuan justru menimbulkan efek yang positif dikaitkan dengan hasil prestasi akademik. Sejalan dengan pernyataan Hanson (2007) bahwa remaja perempuan di Amerika dan Afrika mengalami peningkatan prestasi akdemik setelah menjalin hubungan baik dengan ayahnya (Barrett, 2006). Sejalan dengan pernyataan (Taufik, 2014), bahwa menjadi orang tua tunggal harus menanggung semua kebutuhan anak seorang diri, terlebih jika seseorang itu bekerja maka tidak dapat mengikuti dan melihat perkembangan anak secara maksimal. Pangkal masalah yang sering dihadapi oleh seorang orang tua tunggal adalah masalah anak. Anak akan merasa di rugikan dengan hilangnya salah satu orang yang berarti dalam hidupnya. Anak yang di keluarga yang hanya memiliki orangtua tunggal cenderung kurang mampu mengerjakan sesuatu dengan baik di bandingkan dengan anak yang berasal dari keluarga yang orang tuanya utuh. Hal tersebut dapat menimbulkan dampak yang kurang baik pada anak di akibatkan oleh keadaan orang tuanya.

Bagi kebanyakan ayah mempunyai hubungan yang baik dan mendalam dengan anak dapat mempengaruhi kesehatan emosional dan psikologis secara signifikan untuk ayah dan juga untuk anak perempuan (Berry, dalam Morman \& Floyd, 2006). Perilaku komunikasi dimasa depan pada anak juga berpengaruh dari bagaimana kedekatannya dengan ayah pada waktu kecil, keberhasilan dalam berpikir rasional dengan pasangan ketika sudah dewasa nanti, berpengaruh pada prestasi dalam pendidikan. Bahkan McLanahan \& Sindefur (1994) menyatakan bahwa anak yang tumbuh tanpa peran seorang ayah akan cenderung sulit untuk dapat lulus dari sekolah tinggi, dan memungkinkan terlibat dalam perilaku kriminal (Morman \& Floyd, 2006).

Hubungan antara ayah dengan anak sudah layak menjadi perhatian umum terutama mengenai kualitas dalam hubungan antarpribadi di keluarga yang tidak ideal seperti adanya perceraian atau kematian istri/suami. Kedekatan merupakan suatu aspek yang fundamental dari sebuah hubungan antarpribadi orang tua dengan anak-anak mereka. Hubungan antara ayah dengan anak ini tidak hanya sebatas dalam hitungan waktu hari, minggu, bulan, bahkan tahun, namun mecakup waktu seumur hidup dan memainkan peran penting dalam membentuk identitas antara kedua individu. Karena kualitas hubungan antara ayah dengan anak perempuan secara signifikan dapat mempengaruhi banyak hal yang penting bagi anak perempuan. Misalnya; memahami pikiran atau pendapat antara ke dua individu dalam satu waktu dan mendekatkan kepentingan dalam bernegosiasi suatu hal (Barrett, 2006).

Menurut Charmaz dalam Barrett (2006), hubungan antara ayah dengan anak perempuan juga dapat memberikan pelajaran bagaimana menjalin hubungan dekat dengan orang lain maupun pasangan ketika sudah menjadi dewasa nanti, pelajaran mengenai pengalaman seharihari seperti; bermain dan olah raga atau mengerjakan tugas sekolah dan juga peristiwa penting misalnya menikah dan melahirkan seorang keturunan. Kume (2015) juga mengatakan bahwa ada efek positif perceraian karena adanya pertemuan rutin antara ayah dengan anak perempuannya. Hak asuh bersama merupakan suatu hal yang sangat penting untuk anak yang masih di bawah umur 16 tahun untuk mencegah terjadinya kekerasan dalam rumah tangga, pelecehan seksual, dan kecenderungan perceraian ketika sudah memiliki pasangan suatu saat nanti.

Penelitian sebelumnya juga banyak dilakukan pada anak yang berusia di bawah 16 tahun dan yang paling banyak menjadi responden adalah anak yang berusia 4-12 tahun (Lamb, 2000). Pada usia seperti itu 
lebih mudah mendapatkan hasil yang akurat tetapi harus terjun langsung ke lapangan dan observasi langsung dengan responden Finley and Schwartz dalam Kume (2015). Jika dilihat dari perbedaannya dengan penelitian ini terdapat pada obyeknya, penelitian sebelumnya yang menjadi responden adalah anak sedangkan penelitian ini adalah ayahnya meskipun sama-sama fokus dengan anak yang berumur dibawah 12 tahun.

Mengenai pandangan masyrakat yang menganggap bahwa ayah yang menjadi orang tua tunggal tidak bisa menghasilkan efek yang positif bagi anak perempuannya terutama anak perempuan yang masih dibawah umur 12 tahun adalah suatu hal yang cukup memberatkan. Namun pada kenyataannya keterlibatan ayah menjadi sangat penting dalam hal kemampuan hubungan sosial (Kume, 2015). Namun Morman \& Floyd (2006) meberikan pernyataan bahwa peran sebagai ayah adalah meberikan cinta dan kasih sayang untuk anak, memberikan ketersediaan untuk mengasuh, dan berperan langsung dalam mengasuh anak. Ketiga hal ini cenderung dapat mengatasi hal berpikir anak secara rasional dan emosional sehingga berpengaruh positif juga pada kemampuan hubungan sosial anak.

Naluri ayah dalam mengasuh anak tentu tidak seperti seorang perempuan. Namun, demi sang buah hati, ayah harus bisa menjalankan peran tersebut ketika menjadi ayah tunggal. Sebagai seorang single parent, peran ayah dalam keluarga tentu saja menjadi lebih luas. Selain dituntut memegang peran pencari nafkah, ayah juga harus mengurus berbagai keperluan rumah tangga, yang paling penting memastikan tumbuh kembangnya anak berjalan dengan baik (Dian, 2012).

Penelitian sebelumnya yang dilakukan oleh Algood, Beckert, dan Peterson (2012) menghasilkan pernyataan bahwa keterlibatan pengasuhan seorang ayah berhubungan erat dengan kesejahteraan psikologis anak perempuan mereka. Selain itu juga berkaitan dengan peningkatan kepuasan hidup dan kepercayaan diri seorang anak perempuan. Merujuk pada banyak penelitian sebelumnya yang dilakukan di negara barat mengenai efek dari perceraian dan keterlibatan pengasuhan anak dapat disimpulkan bahwa keterlibatan ayah dengan anak perempuannya menghasilkan efek yang positif setelah terjadinya perceraian. Sedang di Indonesia sendiri banyak anggapan masyarakat yang melihat bahwa seorang ayah yang menjadi orang tua tunggal kurang efektif dalam mengasuh seorang anak (Widaningsih, 2007). Terlebih anak perempuan yang umurnya masih antara 4-12 tahun. Banyak efek yang terjadi dalam diri anak setelah terjadi perceraian orang tuanya. Misalnya kurangnya kepercayaan diri, kurangnya kepuasan hidup, merasa harga dirinya rendah, dan cenderung akan mudah memutuskan suatu hubungan ketika mereka sudah dewasa nanti dikarenakan melihat apa yang sudah terjadi pada orang tuanya ketika ia masih kecil (Kume, 2015).

Hasil penelitian terhadap perkembangan anak yang tidak mendapat asuhan dan perhatian ayah menyimpulkan, perkembangan anak menjadi pincang. Kelompok anak yang tidak mendapat perhatian ayahnya cenderung memiliki kemampuan akademis menurun, aktivitas sosial terhambat, dan interaksi sosial terbatas (Dagun, 1990).

Dilihat dari latar belakang di atas dapat ditarik kesimpulan untuk fokus penelitian ini yaitu bagaimanakah komunikasi antarpribadi dalam memberikan pemahaman mengenai perceraian dan keterlibatan ayah sebagai orangtua tunggal kepada anak perempuannya setelah terjadinya perceraian. Karena keterlibatan ayah dapat merubah efek yang terjadi pada anak setelah terjadinya perceraian. Peran dan komunikasi antarpribadi yang dilakukan ayah pada suatu saat nanti akan dapat mempengaruhi bagaimana anak akan bersikap, menjalani hidup, bersosialisasi, dan meningkatkan kebahagiaan atau kesejahteraan psikologis anak.

Tujuan penelitian ini adalah untuk 
mengetahui bagaimana komunikasi yang dijalin anatara ayah dengan anak perempuannya mengenai pemahaman tentang perceraian dan keterlibatan pengasuhan ayah sebagai orangtua tunggal kepada anak perempuannya setelah terjadinya perceraian. Kemudian, ada dua manfaat dalam penelitian ini, yang pertama adalah manfaat akademis yang diharapkan dapat menambah pengetahuan mengenai ilmu komunikasi antarpribadi dalam sebuah keluarga yang terdapat orangtua tunggal. Yang kedua adalah manfaat praktis yang diharapkan dapat menjadi masukan dan menambah pengetahuan bagi seorang ayah sebagai orangtua tunggal tentang pentingnya komunikasi antarpribadi kepada anak perempuan setelah terjadinya perceraian orangtuanya

\section{B. TELAAH PUSTAKA}

\section{Komunikasi Antar Pribadi dalam Kelu- arga}

Disetiap pasti memiliki kehidupan yang selalu berhubungan dengan keluarga. Keluarga merupakan kelompok yang mengidentifikasi diri dengan anggotanya terdiri dari dua individu atau lebih, Keluarga adalah kelompok sosial terkecil yang timbul akibat adanya perkawinan. Perkawinan adalah suatu kesatuan antara seorang laki - laki atau lebih dengan seorang perempuan atau lebih dalam hubungannya dengan suami istri yang di jamin oleh hukum (Prayoga \& Hidayati, 2013).

Komunikasi antar pribadi adalah proses pengiriman dan penerimaan pesan-pesan antara dua orang atau di antara sekelompok kecil orang-orang dengan beberapa efek dan beberapa umpan balik seketika. Komunikasi antar pribadi merupakan komunikasi di dalam diri sendiri, di dalam diri manusia terdapat komponen-komponen komunikasi seperti sumber, pesan, saluran penerimaan dan balikan. Dalam komunikasi antar pribadi hanya seorang yang terlibat. Pesan mulai dan berakhir dalam diri individu masing-masing. Komunikasi antar pribadi mempengaruhi komunikasi dan hubungan dengan orang lain. Suatu pesan yang di komunikasikan, bermula dari seseorang (Budyatna \& Ganiem, 2011). Dari definisi tersebut, peneliti menyimpulkan bahwa komunikasi antarpribadi adalah penyampaian pesan secara langsung yang dilakukan oleh dua orang atau lebih dan dapat menimbulkan feedback dalam waktu yang sama dan dapat mempengaruhi satu sama lain.

Menurut Cangara (2002), dilihat dari sifatnya komunikasi antarpribadi dapat dibedakan menjadi dua macam yaitu komunikasi diadik dan komunikasi kelompok kecil. Komunikasi diadik adalah proses komunikasi yang berlangsung antara dua orang dalam situasi tatap muka. Sedangkan komunikasi kelompok kecil adalah komunikasi yang berlangsung antara tiga orang atau lebih secara tatap muka dimana anggota-anggotanya saling berinteraksi satu sama lainnya. Pada penelitian ini komunikasi yang dijalin adalah komunikasi dua orang yaitu seorang ayah dengan seorang anak, jika dilihat dari sifatnya termasuk dalam komunikasi diadik.

Komponen-komponen yang berperan dalam komunikasi antarpribadi adalah komunikator, encoding, pesan, saluran atau media, komunikan, decoding, umpan balik, gangguan, dan yang terakhir adalah konteks komunikasi (Cangara, 2002).

Keluarga adalah kelompok kecil yang memiliki pemimpin dan anggota, mempunyai pembagian tugas dan kerja, serta hak dan kewajiban bagi masingmasing anggotanya. Keluarga adalah tempat pertama dan yang utama di mana anak-anak belajar. Dari keluarga mereka mempelajari sifat keyakinan, sifat-sifat mulia, komunikasi dan interaksi sosial, serta keterampilan hidup (Helmawati, 2014).

Komunikasi keluarga adalah suatu kegiatan yang pasti terjadi dalam kehidupan keluarga. Tanpa komunikasi, sepilah kehidupan keluarga dari kegiatan berbicara, berdialog, bertukar pikiran akan 
hilang. Akibatnya kerawanan hubungan antara anggota keluarga sukar dihindari, oleh karena itu komunikasi antara suami dan istri, komunikasi antara orang tua dengan anak perlu dibangun secara harmonis dalam rangka membangun hubungan yang baik dalam keluarga (Djamarah, 2004).

Komunikasi antarpribadi dalam keluarga sangat penting karena dengan adanya komunikasi antarpribadi antara sesama anggota keluarga maka akan tercipta hubungan yang harmonis dan dapat diketahui apa yang diinginkan dan yang tidak di inginkan oleh salah satu anggota keluarganya. Yang dimaksud dengan komunikasi antarpribadi dalam keluarga adalah hubungan timbal balik antara anggota keluarga untuk berbagi berbagai hal dan makna dalam keluarga. Tujuannya untuk mengetahui dunia luar untuk mengubah sikap dan perilaku (Rejeki, 2008).

Teori ini berkaitan dengan pernyataan Kume (2015), yang mengatakan bahwa seorang anak yang diasuh oleh orangtua tunggal akan bermasalah dalam hal perilakunya. Maka penelitian ini ingin mengetahui bagaimana keterlibatan pengasuhan ayah sebagai orangtua tunggal kepada anak perempuannya setelah terjadinya perceraian. Karena pendidikan yang utama dan pertama bagi anak adalah keluarganya.

\section{Pengasuhan Ayah Kepada Anak Perem- puan}

Komunikasi antarpribadi dalam keluarga menjadi sangat penting dan perlu diutamakan karena latar belakang keluarga yang sudah tidak lagi ideal sebagaimana keluarga normal lainnya yang anggotanya masih utuh. Fungsi komunikasi antarpribadi dalam keluarga ini mengacu pada fungsi komunikasi sosial dalam hal keterlibatan pengasuhan seorang ayah sebagai orang tua tunggal kepada anak perempuannya. Proses komunikasi antarpribadi ini ditanamkan sejak dini agar di dalam kehidupan bermasyarakat tidak ada ketegangan dan tekanan dikarenakan adanya pandangan masyarakat yang menilai bahwa seorang ayah tidak bisa menjadi orang tua tunggal bagi anak perempuannya. Dalam sisi lain bahwa seorang ayah yang mengasuh seorang diri dapat menjamin kebahagiaan dan kesejahteraan psikologis anak perempuannya ketika sudah menjadi dewasa. Cooper, dalam Kume (2015), menyatakan bahwa keberhasilan anak perempuan menentukan karier ketika dewasa karena keterlibatan pengasuhan seorang ayah. Hubungan yang dimiliki oleh seorang anak perempuan dengan ayahnya menjadi hal yang sangat mempengaruhi hidupnya dan hubungan ini di mulai ketika masih anak-anak sampai menjadi dewasa. Jika dibandingkan dengan hubungan anak perempuan dengan pasangannya, maka hubungan antara ayah dengan anak perempuan akan lebih memiliki pengaruh yang signifikan (Katorski, 2003).

Menurut Doherty, Kouneski, dan Erickson dalam Kume (2015), ada tiga dimensi dalam pengasuhan ayah sebagai orang tua tunggal yaitu keterlibatan, tanggung jawab, dan aksesibilitas. Keterlibatan yang dimaksudkan adalah sejauh mana seorang ayah mengalami kontak langsung dan berbagi dengan anak-anaknya dalam konteks perawatan atau pengasuhan, bermain, dan aktivitas sehari-hari. Selanjutnya, tanggung jawab adalah bagaimana seorang ayah mengatur kebutuhan kehidupan anak-anaknya dari makanan dan semua fasilitas yang diperlukan oleh anaknya. Yang terakhir, aksesibilitas dapat diartikan sebagai kehadiran seorang ayah dan waktu yang diberikan kepada anaknya.

Keterlibatan seorang ayah dalam pengasuhan anak dari bayi menciptakan efek yang positif dan signifikan. Ketika seorang ayah diberikan kesempatan untuk mengekspresikan kasih sayang mereka terhadap anak-anaknya, mereka akan lebih lembut dan lebih ekspresif. Jika seorang anak di asuh oleh ayahnya sejak kecil, seorang anak akan lebih lekat terhadapa ayahnya, namun jika anak di asuh pada masa sudah remaja atau dewasa maka mereka 
akan lebih dekat pada suatu saat nanti atau jika memang sedang membutuhkan keterlibatan seorang ayah (Parke, 1996). Kotelchuck (1976) mengatakan bahwa kemampuan hubungan sosial yang baik dengan masyarakat juga merupakan efek lain dari keterlibatan seorang ayah terhadap anak perempuannya.

Menurut pengertian di atas dalam kaitannya dengan penelitian ini adalah obyek dari penelitian ini yang berfokus pada ayah sebagai orang tua tunggal yang memiliki tiga anak perempuan yang masingmasing usianya masih di bawah 12 tahun. Hal ini tentu saja mereka di besarkan sejak kecil atau di asuh oleh ayahnya sejak kecil dan banyak pembelajaran utama yang di dapatkan dari seorang ayah di bandingkan dari seorang ibu. Keterlibatan ayah dalam pengasuhan lebih banyak di bandingakan seorang ibu.

Perkembangan anak yang dibesarkan dari keluarga utuh berlawanan dengan keluarga yang yang bercerai. Karena anak yang dibesarkan dalam keluarga bercerai mempunyai tingkat kesejahteraan psikologis yang rendah, tingkat pendidikan yang rendah, dan kurangnya kepuasan dalam menjalani kehidupan berkeluarga atau menerima keadaan pernikahan orangtuanya, dan pasti akan mempunyai masalah dalam hal perilaku dan tekanan mental (Amato dan Keith, 1991).

Orang tua yang sudah bercerai namun masih saling mengasuh anak secara bersama-sama akan berdampak lebih baik dibandingkan jika harus mempunyai orangtua yang bercerai dan melakukan pengasuhan sendiri sebagai orang tua tunggal, karena hal ini akan menimbulkan efek yang negatif dalam hal sikap sosial (Buserman, 2002). Melakukan pengasuhan bersama tidak berarti berada dalam satu atap atau tinggal bersama dalam satu rumah pada orangtua yang sudah becerai, namun masih saling berhubungan baik antar kedua orangtua untuk membicarakan mengenai pengasuhan anak. Penelitian Wellerstein (2000) mengungkapkan bahwa anak yang memiliki kontak konsisten atau berkomunikasi secara rutin dengan orang tuanya yang tidak tinggal satu rumah akan menimbulkan efek yang positif di bandingkan jika anak harus kehilangan kontak dengan orangtua mereka yang tidak tinggal bersama dalam satu rumah. Hal ini berkaitan dengan perkembangannya psikologisnya dalam menyesuaikan diri dengan kehidupan sekitar yang berbeda dengan apa yang di alaminya setelah terjadinya perceraian antara kedua orang tuanya.

Sebaliknya, kurangnya kontak atau komunikasi yang efektif dengan orangtua setelah terjadinya perceraian dapat menyebabkan rendahnya harga diri seorang anak, kurangnya kepercayaan diri, hingga dapat menimbulkan depresi. Selain itu, ketika sudah dewasa atau sudah menikah perceraian cenderung akan terulang kembali pada mereka. Anak-anak yang dipisahkan dari orangtuanya atau sama sekali tidak memiliki kontak dan komunikasi yang efektif dengan orang tuanya memiliki kecenderungan tinggi untuk mudah memutuskan sebuah hubungan termasuk ketika sudah menikah nanti (Baker, 2007). Anak-anak yang mempunyai latar belakang keluarga yang terganggu atau latar belakang perceraian pada umumnya kurang bersosialisasi, mereka memiliki lebih sedikit teman dekat, mengahabiskan lebih sedikit waktu dengan teman-temannya dan lebih sedikit berpartisipasi dalam kegiatan bersama. Namun jika diamati pada anak lakilaki, hasilnya cenderung berbeda karena anak laki-laki dari latar belakang perceraian memiliki kontak yang lebih besar dengan teman-temannya (Parish, 1981).

Salah satu fungsi keterlibatan ayah kepada anak perempuannya adalah tentang memilih pasangan ketika sudah menjadi dewasa nanti. Laki-laki pertama yang di lihat dan dikenal dekat oleh anak perempuan adalah ayahnya. Ayah sangat berperan dalam mambangun kepercayaan diri dalam hubungan sosial dengan lawan jenis ketika sudah remaja atau dewasa nanti (Williamson, 2004). Wyckoff dalam Kume (2015), mengatakan bahhwa keterlibatan 
ayah berdampak lebih besar dalam pemilihan pasangan ketika sudah dewasa nanti, sedangkan ibu lebih pada bagaimana mengajarkan agar seorang anak dapat menjalin hubungan yang baik dengan pasangannya. Barrett (2006) memberikan pernyataan bahwa menjalin hubungan yang baik dengan pasangan kuncinya adalah benar-benar konsekuen dengan hubungan yang sedang di jalani.

Lee, Kusher, dan Cho (2007) mengatakan bahwa hubungan yang baik antara ayah dengan anak perempuannya akan memberikan efek yang positif dalam peningkatan hasil prestasi akademik. Sedangkan Nielsen (2011), menyebutkan bahwa beberapa dekade ini hubungan ayah dengan anak akan rusak dikarenakan perceraian kedua orang tuanya bukan dikarenakan hanya sebatas adanya masalah antara ayah dengan anak. Dengan demikian memahami komunikasi antarpribadi ayah sebagai orang tua tunggal dengan anak perempuannya mengenai keterlibatan pengasuhan dalam hal perkembangan kedekatan mereka sudah dilakukan oleh (Barrett, 2006). Peneliti tertarik untuk mengetahui keterlibatan pengasuhan ayah sebagai orang tua tunggal kepada anak perempuannya akibat terjadinya perceraian. Penelitian ini menggunakan pendekatan studi kasus komunikasi antarpribadi di Desa Kwangsan, Kecamatan Jumapolo.

\section{METODE}

Penelitian ini menggunakan metode Deskriptif Kualitatif untuk mendeskripsikan dan menganalisis fenomena, peristiwa, aktivitas sosial, sikap kepercayaan, persepsi, pemikiran orang-orang secara individual maupun kelompok (Sukmadinata, 2013), yaitu untuk mengetahui bagaimana komunikasi antarpribadi mengenai perceraian dan keterlibatan seorang ayah yang menjadi orangtua tunggal kepada anak perempuannya setelah terjadinya perceraian. Penelitian ini menggunakan teknik Purposive Sampling dengan kriteria sebagai berikut; 1) Seorang ayah yang menjadi orangtua tunggal di Desa Kwangsan, Kecamatan Jumapolo dengan latar belakang akibat terjadinya perceraian hidup, 2) mempunyai anak perempuan yang berusia kurang dari 12 tahun yang sedang dalam pengasuhan ayah. Dari kriteria tersebut ada 3 orang yang terpilih sebagai informan dalam penelitian ini.

Pengumpulan data dalam penelitian ini menggunakan metode wawancara dan observasi. Wawancara ini bersifat semitersruktur karena terbatasnya waktu. Proses pelaksanaan wawancara dilakukan pada bulan Mei 2016, dan direkam dengan media perekam audio untuk memudahkan. Proses wawancara ini menggunakan bahasa Jawa karena informan adalah orang yang terbiasa menggunakan bahasa Jawa, sehhingga diharapkan akan ada kedekatan emosional antara peneliti dan informan. Kemudian hasilnya akan diterjemahkan sendiri oleh peneliti menggunakan bahasa Indonesia dikarenakan peneliti sudah fasih dalam berbahasa Jawa. Jenis observasi dalam penelitian ini adalah observasi non partisipatif karena peneliti tidak terlibat langsung dalam keluarga tersebut namun peneliti memiliki pemahaman mengenai kondisi keluarga yang bercerai karena peneliti adalah salah satu dari anak yang orangtuanya mengalami perceraian tetapi dalam pengasuhan Ibu. Dalam penelitian ini data diperoleh dari tiga orang informan. Informan yang menjadi sumber data primer adalah ayah yang menjadi orangtua tunggal yang kesemuanya mempunyai anak perempuan dalam pengasuhan mereka.

Analisis data dilakukan dengan cara memberikan kode pada tema-tema yang muncul agar menjaga kerahasiaan data diri informan. Selanjutnya dilakukan kategorisasi terhadap tema-tema tersebut guna menemukan jawaban penelitian. Adapun kode-kodenya sebagai berikut;

- Wawancara dengan informan 1: Wawancara dengan informan pertama yang mempunyai anak perempuan kelas 4 SD dan bekerja di sekitar rumahnya.

- Wawancara dengan informan 2: Wawancara dengan informan ke dua 
yang mempunyai anak perempuan di bawah umur 5 tahun yang masih PAUD dan bekerja sebagai Guru SMP.

- Wawancara dengan informan 3: Wawancara dengan informan ke tiga yang mempunyai anak perempuan kelas 3 SD dan bekerja di rumah membuka cuci mobil.

- Pa (Poin A): Proses komunikasi antar pribadi dalam keluarga

- $\mathrm{Pb}$ (Poin B): Keterlibatan dalam pengasuhan

- Pc (Poin C): Tanggung jawab orangtua tunggal dalam mengasuh anak perempuan

- Pd (Poin D): Aksesibilitas

- $\quad$ 1,2,3...dst : Nomor percakapan dengan informan

Teknik analisis data penelitian ini menggunakan model analisis Miles dan Huberman, dimana kegiatan analisis data terdiri dari tiga alur kegiatan yang terjadi secara bersamaan, yaitu reduksi data, penyajian data, dan penarikan kesimpulan atau verifikasi sesuatu yang jalin menjalin merupakan proses siklus dan interaktif pada saat sebelum, selama, dan sesudah pengumpulan data dalam bentuk sejajar untuk membangun wawasan umum yang disebut "analisis" (Silalahi, 2012).

Validitas data dalam penelitian ini menggunakan teknik Trianggulasi. Teknik Trianggulasi adalah teknik yang menganalisis jawaban subjek dengan meneliti kebenarannya dengan data empiris atau sumber data lainnya yang tersedia (Kriyantono, 2010). Teknik Trianggulasi yang digunakan dalam penelitian ini adalah teknik Trianggulasi sumber, yaitu membandingkan atau mengecek ulang derajad kepercayaan suatu informasi yang di peroleh dari sumber yang berbeda.

\section{HASIL DAN PEMBAHASAN}

Dari hasil penelitian diperoleh empat kategori dalam pengasuhan seorang ayah sebagai orangtua tunggal terhadap anak perempuannya, yakni; (1) proses komuikasi antarpribadi dalam keluarga, (2) keterlibatan, (3) tanggung jawab, dan (4) aksesibilitas. Berikut ini dipaparkan secara terperinci untuk masing-masing tema.

\section{Proses Komunikasi Antarpribadi dalam Keluarga}

Informan dalam penelitian ini menyatakan bahwa, pada umumnya ada saudara yang yang dapat mengisi sosok keibuan untuk anak perempuan dari seorang ayah yang menjadi orangtua tua tunggal untuk membantu mengasuh ketika ditinggal bekerja. Namun ada satu informan yang menyatakan bahwa anak perempuannya tidak mempunyai kedekatan dengan perempuan lain dikarenakan memang keadaan mereka yang dalam satu rumah hanya ada ayah dengan anak perempuan tersebut.

"Perempuan yang paling deket ya paling mbak titin. Heem..soale yang di rumah kan cuma itu, lainnya kan merantau. Cuma nek pas pulang ya deket semua dek. Kaya nek pas lebaran, ya cedak kabeh (Perempuan yang paling deket ya paling mbak titin. Heem..soalnya di rumah kan Cuma itu, lainnya kan merantau. Cuma kalau lagi pualang ya dekat semua dek. Kaya pas lebaran ya dekat semua)" - (Wawancara dengan informan 3/Pa, 4. Tanggal 26 Mei 2016)

Dari kutipan wawancara di atas nampak bahwa ada perempuan yang dekat dengan anak perempuan yang sedang dalam pengasuhan ayahnya sebagai orangtua tunggal. Dalam kesehariannya anak perempuan biasanya dekat dengan tante dan neneknya, kerena memang masih dalam satu lingkungan rumah. Meskipun ketika hari-hari tertentu seperti lebaran anak perempuan dekat dengan keluarga lain, namun hal ini terjadi dalam beberapa waktu saja, artinya tidak setiap hari. Jadi, bisa dikatakan bahwa anak perempuan tersebut menjalin kedekatan hanya dengan satu orang perempuan tidak dengan banyak orang (perempuan lain).

"Ora! kae lak mbahe enek, enek kancane momong. Nek aku kui ora enek, yo 
neng omah kan muk wong 2. (enggak! itu kan ada neneknya, ada temennya mengasuh. Kalau aku gak ada. Ya di rumah kan cuma berdua)" - (Wawancara dengan informan 1/Pa, 15. Tanggal 17 Mei 2016)

Menurut pernyataan informan pertama di atas, menunjukkan bahwa salah satu anak perempuan tidak mempunyai kedekatan dengan perempuan lain. Karena dalam satu rumah hanya terdapat dua orang saja, yaitu ayah dan anak perempuannya. Dan kebetulan dil ingkungan tempat tinggalnya tidak saling berdekatan dengan rumah yang lain. Meskipun mempunyai banyak kerabat perempuan, dan jangkauan antar rumahnya tidak jauh namun menurut observasi peneliti untuk menguatkan wawancara, anak perempuan ini juga tidak mempunyai kedekatan dengan perempuan lain.

Mengasuh anak secara mandiri tentu saja tidak mudah, terlebih bagi seorang ayah. Menjadi orangtua tunggal tidak semudah jika menjadi orangtua yang bersama-sama mengasuh dan membesarkan anak berdua dengan pasangan atau istri. Kesulitan dan hambatan sering menjadi masalah dalam menjalani proses pengasuhan, terlebih seorang ayah dengan anak perempuan yang masih kecil. Mengasuh dan mendidik anak kecil tidak semudah jika di bandingkan dengan mengasuh anak yang sudah remaja dalam konteks pengasuhan sehari-hari seperti mandi, mencuci pakaiannya, dan menyiapkan makannya. Jika sudah remaja atau anak yang sudah besar tentunya mereka akan lebih bisa melakukannya dirinya sendiri tanpa harus memerlukan bantuan orangtuanya. Namun ketika anak masih kecil atau kurang dari 12 tahun terkadang makan, menyiapkan makanan, dan mandi masih memerlukan bantuan orangtuanya (Taufik, 2014).

Terkait dengan masalah kesulitan dan hambatan menjadi orangtua tunggal ini pada umumnya ayah dari anak perempuan yang masih kecil ini tidak di jadikan sebuah hambatan dan kesulitan. Karena memang keadaan yang mengharuskan mereka menjadi orangtua tunggal. Maka dari itu mereka harus dapat menerima dengan baik dan menyesuaikan keadaan agar tidak menjadi beban bagi mereka. Jadi, ketika menjalani peran ganda mereka sebagai orangtua tunggal akan merasa lebih nyaman mengingat semua peran yang di lakukan adalah sebuah tanggung jawab. Berikut kutipan wawancaranya;

"Nek masalah kesulitan kesusahan, yo biasa sih yo, mergo keadaan kui dadi wes terbiasa. Dadi kudu menyesuaikan kabeh..si anak yo di mandiin gampang, nyiapke susu yo gampang, di sisir $i$ rambute yo gampang..dadi yo muk menyesuaikan dadine luwih penak, nyantai. (kalau masalah kesulitan kesusahan, ya biasa sih ya, karna keadaan itu jadi udah terbiasa, jadi harus menyesuaikan semuanya. Anak ya mudah di mandiin, nyiapin susu juga mudah, menyisir rambut juga mudah. Jadi cuma menyesuaikan jadi lebih enak, santai)" - (Wawancara dengan informan 2/Pa, 8. Tanggal 17 Mei 2016)

Dalam keluarga dipenelitian ini, ketiganya mempunyai latar belakang yang sama yaitu perceraian (perpisahan antara kedua orangtuanya). Melihat latar belakang tersebut tentunya anak perempuan ini masih mempunyai sosok ibu meskipun sedang jauh atau sedang tidak bersama menjadi kekuarga yang ideal pada umumnya. Dari wawancara ini di temukan hasil yang sama yaitu ketiga ayah yang menjadi orangtua tunggal tidak melibatkan ibu (mantan istri) untuk memberikan pengertian dan pemahaman kepada anak perempuannya mengenai keadaan yang sedang mereka jalani.

Alasan mereka tidak melibatkan peran istri dalam proses komunikasi antar pribadi ini karena memang antara anak dengan ibunya sudah jarang melakukan komunikasi dan jarang bertemu. Atau komunikasi namun hanya pada waktu tertentu dan tidak memiliki jadwal yang tetap. Mengingat bahwa ibu dari anak perempuan dan ayah sebagai orangtua tunggal ini sudah saling memiliki kesibukan sendiri-sendiri, selain itu ayah juga tidak mengharuskan ibunya 
(mantan istri) untuk selalu menghubungi anak perempuannya dengan alasan agar menjadi inisiatif dari mantan istri. Walaupun seorang ayah tidak membatasi anak untuk berkomunikasi dengan ibunya termasuk juga untuk bertemu. Seperti yang disampaikan pada wawancara berikut;

"Oh..enggak. Ora enek..nek komunikasi yo wes biasa..wes nduwe urusan dewedewe dadi yo ra tau komunikasi meneh (Gak ada. Komunikasi ya udah biasa.. udah punya urusan sendiri-sendiri jadi udah nggak pernah komunikasi lagi)" - (Wawancara dengan informan 12/Pa, 10. Tanggal 17 Mei 2016)

Hasil penelitian menunjukkan bahwa seorang ayah yang menjadi orangtua tunggal mempunyai cukup kedekatan dengan anak perempuannya. Melihat bahwa mereka adalah keluarga yang tidak ideal, maka ayah mempunyai cara tersendiri untuk menjalin komunikasi antar pribadi dengan anak perempuannya. Umumnya seorang ayah tidak memberikan pengertian mengenai perceraian, namun dengan cara memberi pemahaman mengenai pekerjaan ibunya. Sejalan dengan pernyataan Josep A. Devito dalam Cangara (2002), bahwa komunikasi antar pribadi adalah proses pengiriman dan penerimaan pesan-pesan antara dua orang atau di antara sekelompok kecil orang-orang dengan beberapa efek dan beberapa umpan balik seketika. Respon atau umpan balik yang didapatkan dari anak perempuan cukup bagus. Walaupun terkadang masih menanyakan sosok ibunya, menjadi hal yang wajar sebagai naluri anak kecil yang masih kurang dari 12 tahun. Karena pada masa-masa seperti ini sebenarnya sosok ibu adalah sosok yang sangat penting kehadirannya.

Menurut sifatnya, komunikasi yang dijalin antara ayah dengan anak perempuan ini adalah komunikasi diadik, karena proses komunikasinya berlangsung antara dua orang secara tatap muka (Cangara, 2002). Adanya anggota keluarga lain dalam keluarga ini namun ayah sebagai orang tua tunggal meskipun berperan ganda tetapi tidak melibatkan orang lain. Dalam menjalin komunikasi antar pribadi dengan anak perempuannya.

\section{Keterlibatan Pengasuhan Ayah Sebagai Orang Tua Tunggal}

Menjadi orangtua tunggal dan melakukan kegiatan sehari-hari secara mandiri yang artinya tanpa ditemani oleh pasangan (istri) dan berperan ganda dalam memenuhi kebutuhan keluarga memang cukup berat. Karena adanya tanggung jawab yang harus di penuhi oleh seorang ayah dalam keluarga tentunya harus dapat menyesuaikan keadaan.

"Yoo kan, pa yaa..istilahe kan..kita kan jaman saiki ada laundry yaa..kita untunge kan disitu ya dek. Dadi ya wes kaya pakaian e gitu ya wes praktis ya dek..jadi paling ya Cuma nyiapne sabune, odole, nek entek yo ditukokne.. tapi kan yo wes iso mandi dewe.. nganggo baju dewe..paling nek kurang rapi yaa di rapiin pake.. Yoo yoo iyoo.. yo emang kudu saya akui..saya mandiri gitu dek..yo dari segi maem dari segi pakaian yo tak siapkan lah yoo.. (ya kan jaman sekarang udah ada laundry, udah praktis, untungnya sih disitu ya dek..jadi paling cuma nyiapin sabun, pasta gigi, kalo habis ya dibeliin, kan udah bisa mandi sendiri, pake baju sendiri..cuma kalo belum rapi ya dirapiin bapak.. saya akui saya mandiri dek dari segi pakaian, makanan, semua saya siapin)" - (Wawancara dengan informan 3/Pb, 2-3. Tanggal 26 Mei 2016)

Menurut kutipan wawancara dengan informan yang ke tiga di atas, seorang ayah terlibat langsung dalam mengasuh anak, meskipun ada anggota lain di rumah namun mereka sudah mempunyai kepentingan sendiri-sendiri sehingga ayah sebagai orangtua tunggal tidak melibatkan orang lain dalam hal pengasuhan, kecuali dalam keadaan mendadak sedang ditinggal bekerja atau pergi.

Seiring kemajuan jaman, ayah juga memanfaatkan jasa laundry untuk membantu mencucikan pakaiannya. Dan ketika anak belum rapi, ayah yang berperan 
langsung untuk merapikan pakaian anak perempuannya. Menjadi orangtua tunggal memang dituntut harus selalu mandiri dalam segala hal termasuk berperan langsung dalam kebutuhan anak perempuan.

Pendidikan merupakan suatu hal yang sangat penting, terlebih bagi anak yang masih di bawah umur 12 tahun pendidikan dasar adalah yang utama. Namun pendidikan ke jenjang yang lebih tinggi menjadi sebuah kebutuhan bagi anak dan juga tanggung jawab bagi orangtuanya. Meskipun menjadi orangtua tunggal, ketiga informan dalam penelitian ini sangat memprioritaskan pendidikan untuk anak perempuannya. Ketika suatu saat nanti anak meminta untuk sekolah setinggi apapun maka akan di usahakan, karena sudah seharusnya menjadi tanggung jawab orangtua untuk memberikan pendidikan yang sebaik-baiknya untuk anaknya. Kemudian, dalam merencanakan fasilitas pendidikan, ayah sebagai orangtua tunggal tidak melibatkan mantan istri (ibu dari anak perempuan) untuk ikut dalam memberikan fasilitas pendidikan. Yang artinya adalah ayah tidak meminta kepada mantan istri namun jika anak diberikan fasilitas pendidikan oleh ibunya juga tidak menghalangi agar diterima dengan baik oleh anak perempuannya. Berikut kutipan wawancara dengan informan ke tiga;

"Nek menurut pribadi saya itu kan namanya pendidikan itu kan utama ya dek ya..jadi istilahe..semaksimal saya.. jadi yaa..ke jenjang yang lebih tinggi lah yaa misal pendidikan..mosok iyo pake koyo ngene anake ngko ya kaya ngene ngko kan..hehe..ngono prinsipku dek.. yo asalkan ada niat pasti Allah memberi jalan ngono wae dek..masalah biaya pendidikan itu.. (kalau menurut pribadi saya pendidikan itu kan yang utama ya dek ya..jadi istilahnya semaksimal mungkin ke jenjang yang lebih tinggi.. masak bapaknya kaya gini nanti anaknya ya ikut kaya gini hehe..gitu prinsipku dek..ya asalkan ada niat pasti Allah memberi jalan kalo masalah biaya pendidikan itu..) - (Wawancara dengan informan 3/Pb, 5. Tanggal 26 Mei 2016)

Keterlibatan pengasuhan dari penelitian ini menemukan hasil bahwa ayah sebagai orangtua tunggal terlibat langsung dalam pengasuhan anak perempuannya. Menurut Doherty, Kouneski, dan Erickson 1998 dalam Kume (2015), keterlibatan adalah sejauh mana seorang ayah mengalamai kontak langsung dan berbagi dengan anak-anaknya dalam konteks perawatan, pengasuhan, bermain, dan aktivitas sehari-hari. Teori ini sejalan dengan hasil tujuan penelitian ini bahwa seorang ayah mengalami kontak langsung dengan anak perempuannya dalam berbagai macam hal yaitu menyiapkan makanan, menyiapkan pakaian, dan berbagai macam keperluan anak perempuannya dilakukan secara mandiri walaupun dalam satu rumah ada anggota keluarga lain.

Menurut Parke (1996), jika seorang anak di asuh oleh ayahnya sejak kecil, seorang anak akan lebih lekat terhadapa ayahnya, namun jika anak di asuh pada masa sudah remaja atau dewasa maka mereka akan lebih dekat pada suatu saat nanti atau jika memang sedang membutuhkan keterlibatan seorang ayah. Peneliti menemukan hasil yang berkaitan dengan teori ini dilihat dari observasi memang anak perempuan ini lebih dekat dengan ayahnya jika dibandingkan dengan anggota keluarga lain walaupun sama-sama sebagai perempuan.

\section{Tanggung Jawab}

Peran ganda memang sudah identik dengan seorang ayah yang menjadi orangtua tunggal. Tanggung jawab yang dipikul terbilang juga cukup berat. Ketika ayah harus bekerja di luar rumah dan meninggalkan anak demi pemenuhan kebutuhannya, maka tanggung jawab ayah adalah memastikan bahwa anak sudah mengerti dan di titipkan kepada anggota keluarga lain.

"Yo.. yowes pamit..pamit biasa.. Yoo.. kan enek manda iki..kadang tak titipne.. trus Cuma aku kan berusaha kudu mulih 
ngono dek..jadi misal lungo esuk, sore kudu mulih dek..aku yo titip karo mbak titin..jadi titip sak mulihku..tak kon nyiapke maeme barang..yo kadang Cuma tak tinggali duit..nyoh urusono.. aku kan muk ngono dek..(yaudah ak pamitin biasa..ya kan kadang ada manda..kadang aku titipin tp aku berusaha juga kudu pulang enggak nginep, berangkat pagi sore kudu udah pulang dek..aku titip sampai aku pulang..tak suruh nyiapain maemnya juga..ya kadang cuma aku tinggalin uang biar diurusin sama dia, cuma gitu aja dek)" -(Wawancara dengan informan 3/Pc, 2-3. Tanggal 26 Mei 2016)

Seperti kutipan wawancara di atas, ketika ayah sedang pergi maka anak dititipkan kepada tantenya. Namun selalu berusaha agar sore tetap pulang, artinya tidak harus menginap di luar dan meninggalkan anak dengan waktu yang cukup lama. Bentuk tanggung jawab ayah sebagai orangtua tunggal ketika akan pergi di sini yaitu memberikan uang agar di belikan dan di siapkan makanan dan semua kebutuhan untuk anak perempuannya. Begitu pula pada ayah yang lain, mereka mempersiapkan segala sesuatunya yang di butuhkan anak seperti susu, makanan, dan pakaian. Jadi ketika di titipkan pada neneknya semua sudah siap agar tidak terlalu merepotkan orang lain.

Namun ada satu keluarga yang memang karena keadaan hanya dua orang, yaitu ayah dengan anak perempuan. Maka ketika anak sedang sekolah dan ayah bekerja diluar rumah, sebelumnya anak di berikan pengertian dan memberitahukan dimana ayahnya sedang bekerja, agar nanti ketika anak perempuan itu sudah pulang dari sekolah, anak menyusul ke tempat ayahnya bekerja dan sebelumnya sudah di siapkan makanan dirumah. Jadi, ketika ayah sedang pergi memastikan bahwa dirumah sudah ada makanan untuk anak perempuannya. Berikut adalah kutipan wawancara dengan informan pertama mengenai tanggung jawab ketika sedang meninggalkan anak perempuan di rumah; "lyo sakwene gede iki.. ngko mulih sekolah nyusul, tak kandani tak kon maem sek... tak kon golek dewe wes tak cepakne ngono.. lyo wes tak cepaki panganan.. yo nek esuk tetep wes tak gawekne sarapan (lya waktu udah gede ini kalau pulang sekolah nyusul, saya bilang dulu saya suruh makan.. cari sendiri udah saya siapin.. sudah saya siapin juga setiap pagi saya bikinkan sarapan)" -(Wawancara dengan informan 1/Pc, 1-2. Tanggal $17 \mathrm{Mei}$ 2016)

Menjadi orangtua tungal memang harus bertanggung jawab untuk berperan ganda. Tanggung jawab disini meliputi pemenuhan kebutuhan sehari-hari dan kebutuhan masa depan atau fasilitas yang akan diberikan kepada anak. Doherty, Kouneski, dan Erickson (1998), mengatakan bahwa tanggung jawab adalah bagaimana seorang ayah mengatur kebutuhan kehidupan anak-anaknya. Hasil temuan penelitian ini adalah ayah sebagai orangtua tunggal akan memberikan fasilitas yang sebaik-baiknya dalam hal pendidikan. Namun dalam konteks kehidupan sehari-hari, pemberian fasilitas di prioritaskan untuk kebutuhan yang penting, karena mengingat seorang ayah harus secara mandiri dalam mengasuh anak dan sekaligus untuk menanamkan pembelajaran menabung bagi anak.

\section{Aksesibilitas}

Aksesibilitas adalah kehadiran seorang ayah dan waktu yang diberikan kepada anaknya. Dalam kaitannya dengan penelitian ini bahwa setiap hari ada waktu dimana orangtuanya menemani kegiatan rutin anak perempuannya. Sekedar meluangkan waktu untuk bermain atau berinteraksi/berkomunikasi agar anak tidak merasa kesepian. Hasil wawancara dengan tiga orang ini ketiganya pada umumnya sama, yaitu setiap hari menemani belajar, bermain, dan menemani aktivitas rutin anak perempuannya. Waktu disini juga menjadi prioritas seorang ayah sebagai orangtua tunggal mengingat mereka adalah keluarga yang tidak ideal maka membuat merasakan kehadiran orangtuanya menjadi sangat 
penting.

Bagi anak perempuan seusia mereka, pada masa ini adalah masa-masa yang sedang sangat membutuhkan teman yang banyak namun tidak selalu ada. Aksesibilitas menjadi sangat penting dan perlu diprioritaskan oleh seorang ayah yang menjadi orangtua tunggal. Menemani setiap kegiatan anak ketika mempunyai waktu luang adalah hal yang dirasa menjadi kewajiban. Latar belakang perceraian atau perpisahan kedua orangtua dari anak perempuan ini akan berpengaruh pada perkembangannya. Maka sebisa mungkin setiap hari seorang ayah yang menjadi orangtua tunggal meluangkan waktu untuk anak perempuannya, seperti pada kutipan wawancara berikut ini dengan informan ke 3;

"lyaa setiap hari dek, tapi nek hari-hari biasa paling bar maem yoo sinau diluk. Bar sinau diluk ngko kita kasih batasan waktu jam setengah 9 kudu bobok. Kadang nek wes sore wes santai wes tutup ngene iki kan yoo..pengen tuku susu..kadang pengen jajan..paling ya gur kui. Paling minta waktu bersama pas ngonokui dek..nek dekne pengen tuku susu pengen tuku jajan ngono uwes.. barkui gek nonton tv mainan ngonokui.. karo mbah kakung juga kadang..(setiap hari kita bareng dek..kalo hari biasa habis maem sore gini ya belajar bentar.. abis belajar nanti kita kasih batasan waktu sampe jam setengah 9 trus bobok. Kadang juga kalo sore udah santai kaya gini minta beli susu minta beli jajan aku anterin abis itu nonton $t v$, sama mbah kakungnya juga kadang) - (Wawancara dengan informan 3/Pd, 1-2. Tanggal 26 Mei 2016)

Seorang anak terutama yang masih kecil atau dibawah umur 12 tahun adalah waktuwaktu dimana anak sangat membutuhkan peran ibunya. Kemudian keadaan dalam keluarga ini anak harus berpisah dan jauh dari ibunya. Maka tugas seorang ayah sebagai orangtua tunggal adalah selalu memberikan waktu untuk anak perempuannya setiap hari agar anak tidak merasa kesepian dengan latar belakang yang disebabkan karena perpisahan antara kedua orangtuanya. Aksesibilitas yang disebutkan oleh Doherty, Kouneski, dan Erickson (1998) adalah kehadiran seorang ayah dan waktu yang diberikan kepada anaknya. Hal ini selaras dengan hasil penelitian ini bahwa setiap hari ayah sebagai orangtua tunggal selalu meluangkan waktu untuk anak perempuannya dan selalu menemani kegiatan rutinnya setiap hari. Seperti misalnya mengantar TPA dan sekolah, atau membimbing belajar, dan sekedar bersepeda bersama. Kegiatan ini akan membuat anak merasa tidak kesepian karena keadaan keluarganya yang tidak ideal.

Pederson dan Robson dalam Kume (2015), juga menyatakan bahwa selain frekuensi pengasuhan dari seorang ayah yang menjadi orangtua tunggal kepada anak perempuannya, interaksi bermain antara ayah dan anak lebih penting karena untuk membentuk penghargaan antara anak dengan ayah. Kaitannya dengan penelitian ini adalah mengenai waktu yang di berikan untuk anak memang lebih banyak dalam kesehariannya dan di anggap prioritas karena fokus dalam kehidupan keluarga pada ketiga informan ini hanya untuk anak perempuannya saja.

Tidak diragukan lagi bahwa ayah itu berperan penting dalam perkembangan anaknya secara langsung. Mereka dapat membelai, mengadakan kontak bahasa, berbicara atau bercanda dengan anaknya. Semuanya itu akan sangat mempengaruhi perkembangan anak selanjutnya. Ayah juga dapat mengatur serta dapat mengarahkan aktivitas anak. Misalnya menyadarkan anak bagaimana menghadapi lingkungannya dan situasi di luar rumah. la memberi dorongan, membiarkan anak mengenal lebih banyak, melangkah lebih jauh, menyediakan perlengkapan permainan yang menarik, mengajari mereka membaca, mengajak anak untuk memperhatikan kejadiankejadian dan hal menarik di luar rumah serta mengajak anak berdiskusi. Semua tindakan ini adalah cara ayah atau orang 
tua tunggal untuk memperkenalkan anak dengan lingkungan hidupnya dan dapat mempengaruhi anak dalam menghadapi perubahan sosial dan membantu perkembangan kognitifnya di kemudian hari (Dagun, 1990).

\section{E. PENUTUP}

Keterlibatan pengasuhan orangtua tunggal dengan anak perempuannya setelah terjadinya perceraian meliputi tiga hal yaitu keterlibatan, tanggung jawab, dan aksesibilitas. Ayah sebagai orangtua tunggal terlibat langsung dan berperan ganda dalam mengasuh anak perempuannya. Tanggung jawab ayah sebagai orangtua tunggal setelah perceraian untuk mengasuh anaknya adalah mengenai tanggung jawab pemenuhan kebutuhan sehari-hari dan perencanaan pendidikan masa depan akan ditanggung secara mandiri dan tidak melibatkan mantan istri atau ibu dari anak perempuannya karena jika sudah dalam pengasuhan ayah maka akan menjadi tanggung jawab ayah. Yang terakhir mengenai aksesibilitas, yang artinya adalah waktu dimana seorang ayah sebagai orangtua tunggal memberikan waktu untuk anak perempuannya setiap hari agar tidak merasa kesepian akibat latar belakang kedua orangtuanya yang sudah bercerai. Seorang ayah setiap hari selalu meluangkan waktu untuk menemani aktivitas dan kegiatan rutin anak perempuannya.

Mengingat keterbatasan penelitian ini yang hanya menggunakan 3 informan maka untuk penelitian selanjutnya agar dilakukan kajian mengenai objek yang cakupan informannya lebih luas dan melibatkan anak perempuan yang sudah memasuki umur remaja untuk dijadikan informan. Agar mendapatkan hasil yang lebih maksimal mengenai pengasuhan ayah sebagai orangtua tunggal dan dapat dicari informan yang lebih banyak. Karena keterbatasan penelitian ini maka untuk penelitian selanjutnya diharapkan tidak hanya berfokus karena latar belakang perceraian saja namun juga karena keadaan lain seperti kematian istri atau atau ibu dari anak. Tidak hanya ayah yang dapat diteliti menjadi orangtua tunggal, begitupun ibu yang menjadi orangtua tunggal dikarenakan latar belakang perceraian maupun kematian seorang suami atau ayah dari anak.

\section{DAFTAR PUSTAKA}

Barrett, E. (2006). Turning points of closeness in the father/daughter relationship. Journal of Chemical Information and Modeling, 53(9), 1689-1699. http://doi.org/10.1017/ CBO9781107415324.004

Budyatna, M., \& Ganiem, L. M. (2011). Teori Komunikasi Antar Pribadi (1st ed.). Jakarta: Kencana.

Cangara, H. (2002). Pengantar Ilmu Komunikasi. Jakarta: Raja Grafindo Persada.

Dagun, S. M. (1990). Psikologi Keluarga. Jakarta: Rineka Cipta.

Dian, S. (2012). Peran Ayah Sebagai Orang Tua Tunggal Dalam Keluarga (Studi Kasus 7 Orang Ayah Di Kelurahan Turikale Kabupaten Maros). Fakultas Ilmu Sosial Dan Ilmu Politik Universitas Hasanuddin Makassar

Djamarah, S. B. (2004). Komunikasi Orang Tua dan Anak dalam Keluarga. Jakarta: Rineka Cipta.

Helmawati. (2014). PENDIDIKAN KELUARGA Teoretis dan Praktis. (N. N. Muliawati, Ed.) (1st ed.). Bandung: PT Remaja Rosdakarya. 
Katorski, J. (2003). Father / Daughter Relationships : Effects of Communicative Adaptability and Satisfaction on Daughter's Romantic Relationships, 1-6.

Kriyantono, R. (2010). Teknik Praktis Riset Komunikasi. Jakarta: Kencana.

Kume, T. (2015). The Effect of Father Involvement in Childcare on the Psychological Wellbeing of Adolescents: A Cross-Cultural Study. New Male Studies: An International Journal, 4(1), 38-51.

Morman, M., \& Floyd, K. (2006). Good Fathering: Father and Son Perceptions of What It Means to Be a Good Father. Fathering: A Journal of Theory, Research, and Practice about Men as Fathers, 4(2), 113-136. http://doi.org/10.3149/fth.0402.113

Parish, T. S. (1981). The impact of divorce on the family.Adolescence, 16(63), 577-586. http:// doi.org/10.1007/BF01434640

Prayoga, S. A. (2013). Pola Pengasuhan Anak Pada Keluarga Orangtua Tunggal (Studi Pada 4 Orangtua Tunggal di Bandar Lampung). Universitas Lampung.

Prayoga, S. A., \& Hidayati, D. A. (2013). Pola Pengasuhan Anak Pada Keluarga Single Parent. Jurnal Sociologie, Vol. 1, No, 106-113.

Purbasari, D., \& Putri, K. (2015). Pembagian Peran Dalam Rumah Tangga. Fakultas Psikologi Universitas Muhammadiyah Surakarta. 16(1), 72-85.

Rejeki, Sry Ayu. (2008). Hubungan Antara Komunikasi Interpersonal dalam Keluarga dengan Pemahaman Moral pada Remaja. Jurnal psikologi. Fakultas Psikologi Universitas Gunadarma

Sari, A. (2015). Model Komunikasi Keluarga Pada Orangtua Tunggal (Single Parent) Dalam Pengasuhan Anak Balita. Jurnal Ilmu Komunikasi, VOL. 3 NO., 126-145.

Silalahi, U. (2012). Metode Peneleitian Pendidikan. Bandung: PT Remaja Rosdakarya.

Sukmadinata, N. S. (2013). Metode Penelitian Pendidikan. Bandung: PT Remaja Rosdakarya.

Taufik. (2014). Dampak Pola Asuh Single Parent Terhadap Tingkah Laku Beragama Remaja (Studi Kasus Dua Remaja PAda Dua Keluarga Single Parent di Dusun Kuden, Sitimulyo, Piyungan, Bantul). UIN Sunan Kalijaga Yogyakarta.

Widaningsih, L. (2007). Relasi Gender Dalam Keluarga : Internalisasi Nilai-Nilai Kesetaraan, $1-7$.

www.bps.go.id. (2015). Retrieved from www.bps.go.id (diakses pada: 25 November, 2015) 